\title{
The External-and-Internal-Forces Model applied to the Japan context ${ }^{1}$
}

\author{
${ }^{1}$ Chukyo University \\ Nagoya, Japan \\ ${ }^{2}$ Meijo University \\ Nagoya, Japan
}

James D'ANGELO ${ }^{1}$ and Saya IKE $^{2}$

\begin{abstract}
This article considers the Buschfeld-Kautzsch 'EIF' (External and Internal Forces) model from the perspective of the Japan context. The model was developed as an enhancement to Schneider's Dynamic Model of Postcolonial Englishes, which is itself an enhancement of the Kachruvian World Englishes paradigm. The EIF is a flexible model that attempts to incorporate the linguistic, social, and historico-political development of English(es) in both postcolonial and non-postcolonial settings: thus addressing the main problem that variety development has heretofore not been systematically analyzed in Expanding Circle contexts. Hence our aim is to see if the EIF model can account for this development in Japan. We incorporate material and data from an eclectic range of historical and current sources. In the process, we consider the historical development of English in Japan from the Meiji Era to the present day, introduce the EIF model in some detail, and assess the usefulness of the model to help explain how English is growing and developing in Japan. The major findings of the article indicate that the EIF model is useful somewhat problematic, and only partly accounts for variety development of Japanese English. We conclude with some recommendations for improving the model through further testing, so it may become a more useful construct for identifying the process of ongoing variety development in non-postcolonial settings.
\end{abstract}

Keywords: Dynamic Model, non-Postcolonial Englishes, world Englishes, Japanese English, Expanding Circle

\section{For citation:}

D'Angelo, James \& Saya Ike. 2020. The External-and-Internal-Forces model applied to the Japan context. Russian Journal of Linguistics 24 (3). 612-632. DOI: 10.22363/2687-00882020-24-3-612-632

${ }^{1}$ This paper is a revised version of a chapter by the authors in the book: Modelling World Englishes: A Joint Approach towards Postcolonial and Non-Postcolonial Varieties, (2020 August) S. Buschfeld \& A. Kautzsch (eds.) Edinburgh: Edinburgh University Press. The authors would like to express their gratitude to EUP for allowing this version to be published in the Russian Journal of Linguistics. 
Научная статья

\title{
Модель внешних и внутренних сил развития английского языка в применении к контексту Японии
}

\author{
Джеймс Д’АНДЖЕЛО', Сая ИКЭ² \\ ${ }^{1}$ Университет Тюкё \\ Нагоя, Япония \\ ${ }^{2}$ Университет Мэйдзё \\ Нагоя, Япония
}

\begin{abstract}
Аннотация
В статье рассматривается модель «внешних и внутренних сил» (ВВС), выдвинутая С. Бушфельд и А. Кауцшем, в применении к контексту Японии. Эта модель является дальнейшей разработкой динамической модели постколониальных вариантов английского языка Э. Шнайдера, которая и сама является развитием теории вариантов английского языка Б. Качру. Она объединяет лингвистическую, социальную и историко-политическую составляющие развития вариантов английского языка как в постколониальном, так и непостколониальном контекстах. В статье обращается внимание на главную проблему, заключающуюся в том, что развитие вариантов в Расширяющемся круге еще не достаточно изучено в системном порядке. Наша цель состоит в том, чтобы посмотреть, можно ли применить модель ВВС для изучения развития варианта английского языка в Японии. Материалом исследования послужили различные исторические и современные источники. Наш обзор затрагивает историческое развитие английского языка в Японии начиная от эпохи Мэйдзи до настоящего времени, с применением модели ВВС; дается оценка целесообразности этой модели для объяснения того, как развивается и активизируется английский язык в современной Японии. Исследование показывает, что модель ВВС несколько проблематична и лишь частично подходит для объяснения особенностей развития японского варианта английского языка. Статья завершается рекомендациями того, как можно усовершенствовать модель путем ее дальнейшего тестирования, так чтобы она стала более приемлемым конструктом для идентификации процесса постоянно продолжающегося развития варианта английского языка в непостколониальном контексте.
\end{abstract}

Ключевые слова: динамическая модель, непостколониальные варианты, варианты английского языка, японский вариант английского языка, Расширяющийся круг

\section{Для цитирования:}

D'Angelo J., Ike S. The External-and-Internal-Forces model applied to the Japan context. Russian Journal of Linguistics. 2020. Vol. 24. № 3. P. 612-632. DOI: 10.22363/2687-00882020-24-3-612-632

\section{Introduction}

Since its first incarnation in 1985, the World Englishes paradigm (Kachru 1985) has been of significant use in helping scholars understand the differences in English varieties viewed from a historico-political lens, and has fostered an appreciation for the diversity and pluricentricity of English. The paradigm was further strengthened by the work of Schneider (2007), who helped to account for a less static, more dynamic and ongoing process of varietal development. Yet these models have been called into question (D'Angelo 2008, Seargeant \& Tagg 2011, 
Seidlhofer 2001) for their excessive focus on describing varieties of English, and their lack of accounting for the greatly increased use of English in the non-postcolonial settings of the Expanding Circle. The EIF model, as proposed by Buschfeld and Kautzsch (2017) addresses these concerns, and makes an important contribution by providing new ways of looking at varieties, while at the same time accounting for the complex use of English in the ever-shifting speech communities of the 21st century. This article considers the case of Japan and its historical involvement with English from the time of earliest contact, and analyses the subsequent development of Japanese English to the present day. We present a careful discussion of applying the EIF model to Japan, from the viewpoints of both Schneider's original model and the enhanced perspective of the EIF model.

\section{Backdrop}

\subsection{The Dynamic Model}

Let us briefly consider the fundamental components of Schneider's Dynamic Model $(2003,2007)$. These will be seen in concrete application in the following section, since the main components are preserved in the EIF. The Dynamic Model consists of five phases. The first is the Foundation Phase, in which English is first introduced into a context through some form of contact with English-speaking entities, typically coinciding with the start of colonization. At this point, there are two groups of language users, English settlers (STL) and the local-language speaking indigenous strands (IDG). The second phase is Exonormative Stabilization, wherein an externally imposed variety becomes stabilized, with increased use of English in various domains. This can be a quite long period, usually during an era of colonization. The strength of the Dynamic Model is that as compared to the static nature of Kachru's three circles, it can account for a great deal of variation in how these phases are realized in each unique context. The third phase is that of Nativization. This can begin prior to national independence through adoption of certain local features, but gains much more momentum after independence. The process then gathers speed, entering a phase of Endonormative Stabilization, in which norms are more locally determined, as wider portions of society use English in official domains and local cultures and languages have more impact on the variety. The final phase is that of Differentiation, wherein the local form(s) of English used by various groups and regions may increasingly diverge. This phase is most common in contexts such as America or Australia, but can be witnessed in Singapore and other post-colonial settings.

The analysis of each phase is framed by four key parameters: 1) extralinguistic factors (e.g., the historical and political development of the country); 2) characteristic identity constructions, factors which change the population's concept of their own identity; 3) sociolinguistic determinants of the contact situation (e.g., conditions of language contact, language attitudes, and use); and 4) structural effects (e.g., the development of lexical, phonological and grammatical 
characteristics). In particular, Schneider $(2003,2007)$ claims that an Event $X$ is crucial in identity construction development, and this usually coincides with independence of the country.

\subsection{Issues with the Dynamic Model}

There have been several attempts to analyse Expanding Circle Englishes from a Dynamic Model perspective (S. Ike 2012, 2014, Schneider 2014). One problem, however, is the missing settler strand (STL) and "Event X" described in the Dynamic Model. Since Japan has never been formally colonized, there are no settler strands that develop the sense of locally-based identity after Event X. Furthermore, the history of Japan shows that there were cases of language contact and of political and sociolinguistic factors for development and domains of English use, but STL has comprised only temporary residents. In other words, Japan lacks the necessary STL element for variety development, and thus cannot be analysed adequately with the Dynamic Model.

To substitute for the missing colonization factor in the Foundation Phase, Edwards (2016) suggests that world-wide globalization may trigger its start. Globalization in current Japan is evident in countless aspects, such as the growth in the number of incoming tourists, steadily increasing numbers of international businesses, and widespread use of the internet and Social Networking Systems (SNS). Inevitably, these conditions affect decisions by Japan's language policymakers, which in turn affect English education, the status of English in various domains, and English-language services for tourists and local non-Japanese residents. Also, we need to consider that Japan seems to have undergone a Foundation Phase in the 1800s. The opening of the country was definitely the start of globalization for Japan.

General attitudes towards English in Japan are at times highly negative (see, e.g., Chiba, Matsuura \& Yamamoto 1995, McKenzie 2008b), and surveys indicate that Japanese people do not claim ownership of English (S. Ike 2012). However, the introduction of English in non-post-colonial English (non-PCE) settings is quite different to that in post-colonial English (PCE) settings, and the spread of English to the Expanding Circle is the spread of the English language, and not of English speakers (Mesthrie \& Bhatt 2008). English is formally introduced to the country, but the need to acquire English is not yet recognized in the first phase. Also, studies (Honna 1995, S. Ike 2012) indicate the distinctiveness of English in Japan, as well as gradual attitude changes in educational settings. Thus, while the Dynamic Model has been widely applied, there is a need for a new model to account for the growing use of English in the Expanding Circle,

Schneider himself acknowledges this (Schneider 2014); he coined the term "transnational attraction" to account for the global boom of English in such contexts as East Asia or continental Europe. Buschfeld and Kautzsch (2017) go on to stress that a more scientific model is needed, and propose the EIF model, as in Figure 1. 


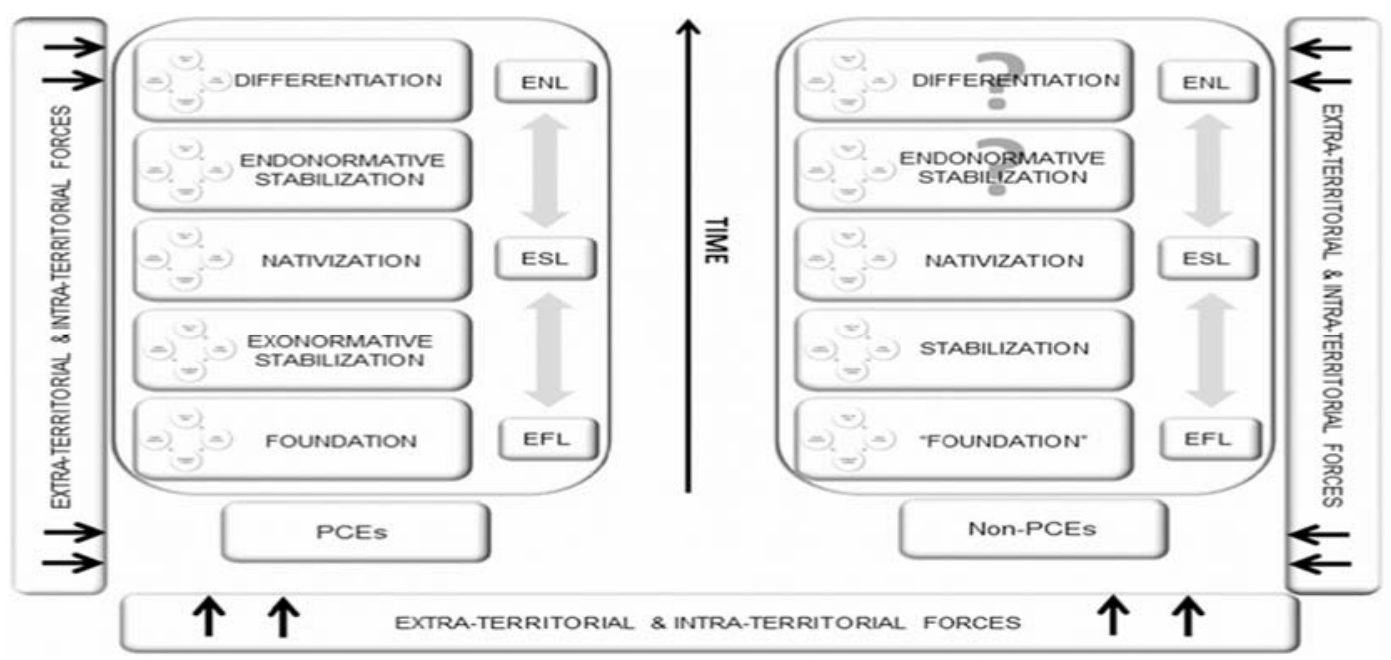

Figure 1. The EIF Model (Buschfeld, Kautzsch \& Schneider 2018: 24)

The EIF maintains the five phases of the Dynamic Model, both for PCE and non-PCE contexts. It does, however, display question marks (see Figure 1) superimposed over phases four and five (Endonormative Stabilization and Differentiation) in the non-PCE column. There are also minor changes to terminology, such as Phase 2 being named "Stabilization" rather than "Exonormative Stabilization" for the non-PCE strand. The model presents the phases as moving along a vertical timeline, starting with Foundation. The sequencing of this timeline will be addressed in our following sections. We should also note that the EIF model introduces boxes to the right of the Foundation, Nativization, and Differentiation Phases, which are respectively given the designations "EFL," "ESL," and "ENL", although ENL is most likely not relevant for the non-PCE contexts (see the question mark placed on phase 5). Unlike the timeline, these designations are presented with bi-directional arrows, indicating that a context could possibly regress in some way to an earlier phase. Finally, one can also see the Extra- and Intra-territorial Forces entering the model from both sides, as well as at the bottom of Fig. 1. Although still included, the four parameters are not explicitly addressed in the EIF model.

In addition to the globalization movement, the EIF model illustrates possible forces-both extra- and intra-territorial-as illustrated in Figure 2. Regarding the specifics of the all-important extra- and intra-territorial forces which provide the main enhancement to the Dynamic Model, they are in two cases given the same title in both extra- and intra-territorial columns ("Sociodemographic background" and "Foreign policies"), but are slightly modified in the three other forces ("Attitudes towards colonizing power" rather than simply "Colonization," "Language attitudes" added to "Language policies," and "Acceptance of globalization" rather than "Globalization"), as seen below in Figure 2. It can also be seen in Figure 2 where an " $\mathrm{x}$ " is found, that Colonization is neither an extra- or intra-territorial force in Non-PCE contexts. 


\begin{tabular}{|c|c|c|c|c|c|}
\hline Extra-territorial Force & PCE & Non-PCE & Intra-territorial Force & PCE & Non-PCE \\
\hline Colonization & $\checkmark$ & $\mathrm{x}$ & $\begin{array}{l}\text { Attitudes towards } \\
\text { colonizing power }\end{array}$ & $\checkmark$ & $x$ \\
\hline Language policies & $\checkmark$ & $\checkmark$ & $\begin{array}{l}\text { Language policies / } \\
\text { language attitudes }\end{array}$ & $\checkmark$ & $\checkmark$ \\
\hline Globalization & $\checkmark$ & $\checkmark$ & $\begin{array}{l}\text { 'Acceptance' of } \\
\text { globalization }\end{array}$ & $\checkmark$ & $\checkmark$ \\
\hline Foreign policies & $\checkmark$ & $\checkmark$ & Foreign policies & $\checkmark$ & $\checkmark$ \\
\hline $\begin{array}{l}\text { Sociodemographic } \\
\text { background }\end{array}$ & $\checkmark$ & $\checkmark$ & $\begin{array}{l}\text { Sociodemographic } \\
\text { background }\end{array}$ & $\checkmark$ & $\checkmark$ \\
\hline
\end{tabular}

Figure 2. The Extra- and Intra-territorial Forces

A consideration of the relevance and usefulness of these forces will be the main focus of Section 3 of the paper, as we apply the model to the Japan context.

\section{Testing the EIF model for Japan}

The EIF model is designed to identify factors that contribute to the development of an English variety in both PCE and non-PCE (Expanding Circle) settings. Thus, we test the model with Japanese English as a case study, starting with a brief history of English in Japan.

\subsection{History of English in Japan}

The first contact with English in Japan was around 1603, and English was briefly used for trading purposes with Britain before Japan closed the country in 1639 (Takanashi \& Ohmura 1975). There is some evidence that a few people attempted to learn English around that time, but there were no institutions for systematic English education (Koscielecki 2006), and there is no record of any emergence of loanwords (Loveday 1996). The need for English arose again in 1808, when the British battleship HMS Phaeton anchored, and marines came ashore and stole supplies in Nagasaki Harbor, one of the two main trading ports at the time. Thus, it can be argued that this incident was an extra-territorial force which triggered the Shogunate to reconsider its defence plan, and to order state interpreters to learn English (Loveday 1996, Stanlaw 2004, Takanashi \& Ohmura 1975). However, the need for English and exposure to it continued to be highly limited, since Japan remained closed and isolated until 1858 (Saito 2001). In 1853 American Commodore Matthew Calbraith Perry came to Tokyo Bay-his actions serving as 
another influential extra-territorial force-and Japan finally opened its doors to international trade, which acted as an intra-territorial force. Mckenzie (2008a) argues that this is the first major contact with English, and the opening of the country was followed by the beginning of the Meiji Restoration in 1868. Although Japan did not experience colonial status and thus English was not introduced as the language of power, the introduction of English is clearly traceable, so it is safe to say that the Foundation Phase began in the early 19th century.

There were a number of sociolinguistic factors (both extra- and intraterritorial) that contributed to the spread of English in Japan. Since there were no English-Japanese interpreters at the time, the Convention of Kanagawa (Kanagawa Treaty) was first translated from English to Dutch by an American, and then from Dutch to Japanese, causing some confusion and leaving Japan at a disadvantage in the trade agreement (Stanlaw 2004). English became an urgent necessity for the government as part of foreign policy and international relations. Meanwhile, Yokohama opened as one of the main ports, creating another domain for English use among traders. Pidgin varieties of Japanese and English developed at the same time among the foreign traders (Kodama \& Kodama 1979, Ohta 1981). Atkinson's (1879, reprinted in 2007) work on pidginized varieties of Japanese and English shows that English speakers assimilated Japanese words to similarly pronounced English vocabulary, but with Japanese meanings. Perhaps the oldest such borrowing was gere+borotaN "Great Britain" - now modified to gureeto+buriteN (cf. Stanlaw 2004). Loveday (1996) also points out that $85 \%$ of the pidgin vocabulary was derived from Japanese. The modified EIF model (Buschfeld, Kautzsch \& Schneider 2018) works particularly well in describing this aspect, via the nativization process.

In the early Meiji period, almost all higher education, including subjects such as English literature and history, were taught by English-speaking teachers in English (Ohta 1981, Takanashi \& Ohmura 1975). Ohta (1981) also states that even Japanese teachers used English as a medium of education in those days. English was an absolute necessity for those elites who wished to study any subject, hence learning English meant gaining advanced Western knowledge in order to "catch up with" the advanced countries, especially Britain. In fact, Takanashi and Ohmura (1975) state that students had to graduate from Tokyo English School, one of the English conversation schools at the time, in order to enter a university. Most of the language institutions that were established had native English speakers as teachers and used American textbooks (Takanashi \& Ohmura 1975). There were seven national English schools and more than a thousand private English schools in the Tokyo area alone in 1873 (Saito 2001). Some scholars describe this phenomenon as semi-colonization (e.g., Imura 2003, Ohta 1981, Takanashi \& Ohmura 1975). This shows that there were strong extra- and intra-territorial forces for the development of Japanese English, leading it to the second phase, Stabilization.

There were mainly two domains for English use, one on the street for international business and day-to-day interactions, and the other within educational 
institutions for the purpose of higher-stakes international relations: both working as intra-territorial forces. Thus, the contact between two languages, as well as the two groups of people, can also be traced. It can be argued that English possessed political power then, as Arinori Mori, later a Japanese Minister of Education, suggested that Japan needed to consider English an official language, claiming the Japanese language lacked communication ability without the help of Chinese elements, and predicting that English would inundate Japan as Japan took in Western culture (Mori \& Ohkubo 1972).

English was used not only in street signs, but also in books for the public. In terms of linguistic development, this is where loanword usage started, and semantic shift, broadening and narrowing started to occur, as is evident in publications from this period. In an effort to integrate English into Japanese, English loanwords were written in Japanese characters, and often they were pronounced quite differently (Honna 1995, 2008, Stanlaw 2004). Saito (2001) and Ohta (1981) also show codemixed examples in Japanese comical poetry (Dodoitsu), in which many English words were used, but not necessarily with the same meaning as in their source English. Charenji_is one well-known example, whereby the meaning in Japanese is much more related to facing an almost insurmountable difficulty. By the late Meiji period (around 1900), more and more ordinary people were becoming familiar with English. Arakawa's dictionary was published in 1931, with 5018 entries of "Japanized English" (Loveday 1996), indicating extensive English nativization in Japan. This suggests that there was some innovative use of English in the Japanese context, functioning as an intra-territorial force, but also as extra-territorial force, leading to the next phase of variety development.

However, when the Meiji period came to an end, English lost its role as a means of gaining Western knowledge (Imura 2003). Moreover, in part as a reaction to early Meiji Westernization, Nationalism emerged and gradually gained support (Saito 2007). A national education system was implemented in 1872, and in the following five years, educated Japanese people started to become English teachers at higher-education institutions. Tokyo University changed its medium of education to Japanese in 1863, and in 1886, the first Minister of Education, Arinori Mori, declared Japanese to be the medium of education (Imura 2003). The need for English decreased considerably, and in 1877, five of the seven national English schools were closed (Ohta 1981, Saito 2001). Even at the remaining two national English schools, only two out of 28 teachers were native English speakers (Ohta 1981). The number of foreign teachers decreased from 503 in 1872 to 77 in 1896 (Imura 2003), and this also reflects nationalism in Japan at the time. The status of English changed from a practical communication skill to just a subject of study. Saito (2001) says that the learning of English was framed as the study of English literature and language, creating controversy over "practical English" and "educational English." A major setback for English variety development in Japan was this nationalism (i.e., counter intra-territorial force) throughout the ensuing war period, starting with the First Sino-Japanese War (1894-1895) and the Russo- 
Japanese War (1904-1905). The bi-directional arrows in the EIF model help account for this type of reversal.

Nationalism led the effort to set up a standard Japanese language from 1902 to 1916, along with the movement for the unification of the written and spoken language (genbun itchi undō) (Carroll 2000). In 1939, names of foreign countries were changed into Chinese characters in the press, and the amount of new English borrowing significantly declined (Loveday 1996). When Japan entered World War II and England and America became her enemies in 1941, there was yet another strong nationalistic movement, and almost all English words disappeared both from written and spoken contexts, and were substituted for by directly-translated Japanese words (Loveday 1996, Ohta 1981, Saito 2001), although English remained a subject in school education throughout the war (M. Ike 1995, Imura 2003). This shows that political and sociolinguistic circumstances, acting as counter-forces, have prevented steady linguistic development, and Japan remained in the early Stabilization Phase till the end of WWII.

Political and sociolinguistic factors changed dramatically between 1945 and 1952, while the US General Headquarters (GHQ) occupied Japan. English was no longer the enemy's language, but a means of survival. Loveday (1996) notes that there were as many as 500,000 American troops stationed in Japan at the time, and people all over Japan, including children and ordinary citizens, used English during the post-war period to ask for food (Ohta 1981). As the contexts for English use expanded, pidginized varieties of English, which were different from the earlier ones, such as Yokohama dialect, appeared once again (Loveday 1996, Stanlaw 2004). This can be viewed as a new period of globalization for Japan, again shifting its foreign and language policies outwards. Language restrictions were no longer enforced, and the education system underwent a major reformation.

Nine years of compulsory education began in 1947, and a great number of people started receiving formal English education at grade 7. However, there were significantly fewer native English speakers in Japan after the end of the occupation, providing much less opportunity for interaction, thus contributing to the disappearance of such pidginized varieties, and English education remained focused on reading and writing (Saito 2001). In short, the GHQ occupation was a strong extra-territorial force, and the following educational reformation was a strong intra-territorial force in reaction to it, but was only influential for a short period of time. Nonetheless, English loanwords reappeared to a greater extent in the streets and in publications, especially in the 1960s and 1970s (Hashimoto 2006). Conversational English textbooks became bestsellers, and English education programs were broadcast and attracted large audiences (Loveday 1996, Saito 2001, 2007).

In post-war Japan, intra-territorial forces such as education policy and sociodemographic forces were present, yet remarkably weak compared to some earlier periods. However, it should be noted that in general, attitudes towards English were 
positive, and with globalization progressing with Japan's explosive economic growth from the 1970s, Japanese citizens became increasingly attracted to English.

\subsection{Japan in modern days}

In modern days, with ever-increasing globalization, the need for English continues to grow, and the motivation for English learning has transmuted from survival to economic success and local interaction. Extra attention is paid in this section to identifying each force.

\section{$i$. Language policies}

A proposal to introduce English as an official language was raised again by Prime Minister Keizo Obuchi in 2000. Although this proposal was rejected, an increasing number of companies are giving English official status for intra-business communication in recent years. Perhaps one of the earliest companies to do so is major electronics component maker Sumida Corporation, which designated English its official language in 1999 (Yoshihara, Okabe \& Sawaki 2001). In 2010, a Japanese electronic commerce and Internet company Rakuten, which has more than 20 million customers worldwide, announced that English would be used for all communication, triggering country-wide controversy. An international retail company Fast Retailing (known for its fashion brand UNIQLO), which has over a thousand branches overseas, introduced English as an official language for all internal meetings in Japan in 2012. Also, international business firms including car manufacturer Honda and cosmetics company Shiseido have been preparing to adopt English as their official language (cf. Kim 2017).

In educational settings, the movement to adopt English is even stronger, thanks to government support (MEXT ${ }^{2} 2014$, also see Murata, Konakahara, Iino \& Toyoshima 2018), and universities have reintroduced English as a medium of instruction (EMI). Kojima (2016) notes that the number of universities which employ EMI increased from seven ( 8 departments) in 2008 to nineteen (38 departments) in 2013. If partial EMI courses of study are included, the number accounts for 36\% of all the courses available in Japan in 2013 (Kojima 2016). English education policy has been changing, too, introducing English as an ungraded 'activity' in primary school education in 2013 (starting in grade 5). Beginning in 2020, the introduction of English as an ungraded activity will take place earlier, in grade 3, and English will become a compulsory subject in grade 5 (MEXT 2003). Prior to this, MEXT proposed an Action Plan in 2002 (MEXT 2002), to "acquire communication skills in English as a common international language," which includes sending an assistant English-language teacher (ALT) to every junior high school and high school at least once a week. An early statement by MEXT included norm-dependent terms such as "a native speaker of English" in describing the nature of ALTs and presenting the motivation of English learning as "[t]o have one's English understood by a native speaker" (MEXT 2003). A more

\footnotetext{
${ }^{2}$ MEXT - Ministry of Education, Culture, Sports, Science and Technology, Japan.
} 
recent statement by MEXT (2013) has dropped the word "native," and simply states "English speakers," and emphasizes "what they can do" - which is a more CEFRlike description of the functions students can do with English, rather than their approximation to native standards. This indicates greater awareness of English as a Lingua Franca (ELF) in the current world, and evaluating a student's communicative ability instead of assessing proficiency against a native norm, as a small step towards Nativization. However, as Murata et al. (2018) point out, EMI and English education in Japan is still highly norm-dependent, which suggests that Japan remains in Exonormative Stabilization today.

The concern, moreover, is that MEXT is pushing more and more schools and students to focus on English education geared for international standardized tests such as TOEIC and TOEFL. This can be considered an intra-territorial force, resulting from institutional pressure on students to perform well on these tests, but at the same time, an extra-territorial force related to those wishing to study overseas and corporate needs for English-proficient staff due to the demands of overseas trading partners. In many cases, the intra- and extra-territorial forces are flip sides of the same coin.

\section{ii. Linguistic forces}

Linguistic forces - reflections of language attitudes - are stronger than ever in Japan. Loveday (1996) states that more than $7 \%$ of the total Japanese lexicon is English-derived loanwords, while the total proportion of loanwords from all languages in Japanese is approximately 10\%. According to research in 1956 (published in 1962-1964) initiated by The National Language Research Institute (NLRI), 9.8\% of the words used in 90 different magazines were loanwords, of which $80.8 \%$ were English words. A more recent survey (Hashimoto 2006) shows that almost $90 \%$ of loanwords used in newspapers are English. Here we see a possibility of further English development in this context. In fact, Honna (2008) notes that those Japanized words have gone through semantic nativization, including semantic broadening, narrowing, and shifting, and S. Ike (2014) argues that these expressions are then used in Japanese English, gaining more recognition over the years and making their way into English reference works. For example, words that were once heavily criticized as "incorrect," such as salaryman (a whitecolour worker) and office lady (a woman working in an office), are now included in Oxford Living Dictionary as well as the Oxford Learner's Dictionary.

Linguistic landscapes in Japan also show some evidence of sociodemographic forces. The annual number of visitors to Japan was approximately 350,000 in 1964, and reached one million in 1977 . The growth rate of visitors was not particularly high until the 2000s. Since the Japanese government led by then prime minister Junichiro Koizumi launched the Visit Japan Campaign (VJP) to increase the number of tourists in 2003 (Japan National Tourism Organization 2003), it significantly increased from just under five million in 2000 to more than 28 million in 2017 (Japan National Tourism Organization 2018). Although Buschfeld et al. (2018) see increasing tourism as an extra-territorial force, it is in fact an intra- 
territorial force in the case of Japan. It should also be noted, however, there were a number of external factors such as the depreciation of the Japanese yen and the economic growth of China in the early 2010s (Andonian et al. 2016), and thus tourism in Japan - and its effect on increased or lessened use of English - needs to be viewed both as intra- and extra-territorial force.

In reaction to the demand for English by overseas visitors, more and more tourist spots and shopping areas are providing multilingual signage and language services (Backhaus 2006). Backhaus (2007) reports that English is often used as the sole language to pass information to non-Japanese in the Tokyo area, and this use of increased signage shows relevant contexts in Japan in which English functions as a communication tool. Backhaus also studies the linguistic landscape diachronically, and illustrates the increase of official English signage in the last 20 years in Japan, as well as the increase of Chinese and Korean in the last ten years (Backhaus 2005). Similarly, S. Ike (2017a), based on her survey of signage at two major train stations in Japan (Kyoto and Nagoya), reports that more than two-thirds of signage regarding location and direction on Japan Railway (JR) platforms are provided in English and Japanese. More recently, a major typhoon which swept the full length of Japan on 30 September 2018 was accompanied by extensive instructions on the NHK television network targeting foreign residents and advising, via easy-to-read enlarged English text visuals, on proper precautions to take. Such actions address not only short-term travellers, but demonstrate the reality of international mobility, and small-scale immigration.

Meanwhile, there is also a natural growth at the grassroots level of those using English through electronic media to interact with friends and associates from around the world. As highlighted by some scholars such as Seargeant and Tagg (2011), the explosion of internet use, and SNS in particular, opens up many opportunities for increased use of English. It is not clear as yet to what extent the ELF-like interaction by Japanese with those from a variety of native-speaker / nonnative-speaker backgrounds may engender further development of Japanese English, but it is sure to have an impact. Recent data indicates that 47.54 million Japanese were users of Social Networking Systems (SNS) in 2015, and is expected to be 63.63 million in 2022 (Statista 2018). Clearly this is both an intra- and extraterritorial force of globalization, which will have an impact on Japanese English, and multilingual language use of the Japanese. Japan is also a dynamo with regard to translation of English fiction and academic/scientific works, with over 50,000 works translated annually (Higuchi 2007). In addition, Japan has produced products such as the professional translation software Trados (SDL 2018), a computer-assisted translation tool which allows for a high degree of accuracy by giving translators a range of options at the phrasal level, allowing for the translator to make the most accurate choice considering the complex variety of usages inherent in language. The extent to which such technological breakthroughs may impact variety development, remains to be seen. 
Partly due to the limited domains of English use, and partly because of English education still largely focusing on reading/writing (Hino 2018), bilingualism in Japan is not very common, and general English proficiency remains low. Honna and Takeshita's (2000) study shows that most university students, who have had at least six years of formal English instruction, are unhappy with their English proficiency, and the average score on the Test of English as a Foreign Language (TOEFL) was ranked 149th of 162 countries, according to the Educational Testing Service (ETS) in 1993. As of 2017, the mean TOEIC score in Japan is 516, compared to that in Korea, 679, Malaysia, 644, and China, 586, although surprisingly, the mean score in Hong Kong, 515, is below that in Japan (ETS 2018a).

Similarly, Japan's mean TOEFL score is ranked 27th among 29 Asian countries (ETS 2018b). Some caution should be observed in using this data, since Japan, as an affluent country, has a large percentage of high school and university students take these tests, many of whom may not be so serious about the future role of English in their lives. Nevertheless, the figures may indicate some lack of an adequate intra-territorial force to strongly promote depth of English proficiency across wider swaths of Japanese society.

The statistics reported here suggest that English has not fully spread in all domains in Japan, and there are a few counter-forces preventing English variety development. In fact, even in large Japanese corporations, only about $10 \%$ of employees will need English for their work (Honna 2008). The use of English is generally limited to communication between English-speaking communities in Japan, and communication between Japan and the outside world (Makarova \& Rodgers 2004). In sum, Japan could be seen to be in a late phase of Exonormative Stabilization or a very early phase of Nativization, but whether it develops further despite all the counter-forces remains to be seen.

\section{iii. Language attitudes}

Lastly, language attitudes need to be examined. The assumption that English is used between Japanese and "native" English speakers held by the very top government policy makers in early 2000s, is accurately reflected in the teachers' and the students' attitudes towards English. For example, Honna and Takeshita's (2000) survey shows that most students learn English in order to communicate with native English speakers; very few have non-native speakers in mind. Butler's (2007) survey also reveals that more than half of elementary school teachers think English is best taught by native speakers. Similarly, according to a survey by Nakai (2003), almost half of the students either in English teaching courses or majoring in English at a university believe that native speakers are more successful in teaching English than non-natives. He concludes that native speakers are seen as ideal English teachers in Japan, given the low confidence of Japanese teachers in pronunciation, authenticity, and accuracy. Greisamer (2006) notes university students' comments such as "real English is better" and "native speakers have better pronunciation" in support of native instructors. The assumption here is that English 
spoken by native speakers is "real" and "authentic," but English spoken by Japanese or other non-native speakers is not, showing that in terms of language attitudes, Japan is still in an early Exonormative Stabilization Phase.

Similarly, students' lower tolerance of Outer- and Expanding-Circle varieties has been reported. McKenzie's study (2008b) shows that Japanese university students evaluated two Japanese English speakers lower than the other four native English speakers (two American and two British) in terms of language competence. Adachi's (2007) questionnaire results show the exclusion of non-native English speakers in students' minds more clearly. While more than $80 \%$ of the students strongly agreed with the statement that they would like to be able to communicate with native English speakers, only $36 \%$ showed strong agreement to the statement that they would like to be able to communicate with people whose mother tongue is not English. Adachi argues that this is due to the lack of awareness of the ELF and World Englishes perspectives among Japanese learners of English.

More recent surveys, however, show that an increasing number of students in Japan are familiar with the concept of World Englishes, and although still few in number, more and more Japanese are in support of Japanese English as a variety, recognising its function as ELF (Hino 2012, Murata et al. 2018). D'Angelo (2016, 2018), based on data from 10 years of graduates and their actual English needs, indicates that students exposed to pluralistic models of English truly see the value of such approaches, out in the working world. He proposes that WE, EIL and ELF can work in harmony in Japan, under the term "The World Englishes Enterprise." There have been various attempts among educators and scholars to integrate the notion of World Englishes (WE) into English teaching in recent years, such as the inclusion of characters with various language/cultural backgrounds in English textbooks (Yamanaka 2006) and specific WE courses in tertiary education (Yoshikawa 2005). In the academic domain, WE is actively discussed in a number of societies, such as The Japan Association of College English Teachers (JACET) and The Japan Association for Asian Englishes (JAFAE).

The importance of recognition and acceptance of Japanese English as a legitimate new variety has been argued by a number of scholars (Hino 2008, 2012, Honna 2008, Honna \& Meinhof 1999, S. Ike 2010, 2012, 2014), and the features and distinctiveness of Japanese English have been discussed (Fujiwara 2012, S. Ike 2012, 2016, 2017b). Studies on acceptability of Japanese English (S. Ike 2012) suggest that Japanese English is intelligible and acceptable in ELF communication, and non-Japanese participants had mostly positive attitudes towards the variety; yet Japanese participants still held fairly negative attitudes (S. Ike 2012). In terms of identity, the ownership of English is still very much L1-oriented, and little evolution of that view is observable. However, these recent movements may suggest that Japan is slowly moving toward a Nativization Phase.

In this section we have considered the history of English in Japan from the time of earliest contact to the present day. The EIF model has been applied to the various developments which have occurred in a diachronic study, and the model, with its flexibility and use of the extra- and intra-territorial forces shows evidence of being 
quite useful in capturing certain aspects of variety development that the Dynamic Model was unable to do.

\section{Discussion and concluding remarks}

As mentioned earlier, there is need for a new model which attempts inclusivity for and concrete analysis of Non-PCEs, since it is common knowledge today that non-PCE users of English outnumber native and PCE users. The previous section suggests that the EIF model works well in Expanding Circle cases, yet shows that the model needs improvement in some areas. In this section, we review the significance of the model and discuss possible modification.

In looking at Japan, the identification of forces in the EIF model partially accounts for the Foundation Phase, and these can help scholars look at factors influencing variety development. The time factor in later phases in the case of Japan (and probably many other Expanding Circle contexts in this volume) is quite compressed as compared with a classic PCE such as that in Singapore, but this is the reality we face today. The incubation period is less important, whereas forces such as language policy, attitudes, and globalization play a much larger role. Identified forces in the model are also quite useful in evaluating the status of English in a given context, and having a set of forces to look for enables scholars to examine and compare English development across nations/regions.

At the same time, our case study indicates that certain points need to be considered. First, distinguishing extra-/intra-territorial forces needs to be further clarified. Often the same forces in the EIF simultaneously act externally and internally. This may make it hard to decide if a particular force is internal or external, but if one realizes that the international roles and use of English are more important for the non-PCE, as well as increasingly for the PCE contexts, such as India's, then one need not be overly concerned about the interplay of the same force on both levels. In terms of the model display, however, bi-directional arrows should be used to show the continuum-like nature of the forces.

Second, while the EIF contains the same five phases as the Dynamic Model, the clear identification of these developmental phases is yet to be explored. It is hoped that with time, progress will be made towards that end. In addition, as outlined in section one, Schneider's four parameters (especially identity re-settings and linguistic developments) are not defined in the EIF model, and these are important considerations in variety development. Hence, the sociolinguistic parameters and linguistic parameters do not necessarily correspond, especially with regard to attitudes and features. The EIF may indicate that identity construction and attitudes towards English are intertwined in one category or force, but identity construction as an "English speaker" and as a "Japanese person" are still two different concepts in early phases, and thus need to be taken into account separately. The model seems to imply that sociolinguistic conditions and structural consequences are synonymous, but the integration of these two aspects may have the effect of eliminating the space for discussion of Japanese English features. 
Third, we argue that the term "exonormative" should remain in the EIF model. In many Expanding Circle cases, in Asian countries in particular, there remains a clear preference for "native" English as a learning model. This means that English has not just been stabilized in a given context but it retains its attribution of ownership to L1 users. Therefore, English is recognized as the language of "others" instead of "ours," and this phase needs to be clearly demonstrated in the model. In some way it remains to be seen whether the extra-/intra- forces can replace the STL/IDG strands of the Dynamic Model. Whether the forces are sufficient to replace the important role of these strands needs to be demonstrated through detailed practical application in further research.

A final point is that other forces not yet identified in the EIF model may need to be sought out and considered. Technological development such as increasingly sophisticated translation software (e.g., Google translate, TRADOS) may act as a counter-force and make variety development in non-PCE contexts a less pressing matter. Another factor which the model does not directly consider is the possibility of "world mindedness" (D'Angelo 2016) or general awareness of world Englishes, potentially acting as an intra-territorial force affecting language attitudes.

Our case study of Japan generally supports the validity of the EIF model, as it allows us to consider variety developments in Non-PCE and PCE settings. The model shows some compatibility between the two settings, especially in identifying the Foundation Phase, although modification such as displaying intra-extra forces in continuum, and clear description of each phase in terms of four parameters, seem to be necessary. The model also considers idiolectal use of English (as speech communities become more dynamic), beyond the consideration of national varieties, and demonstrates the ongoing importance of revising our models to meet the changing conditions of global English use (D'Angelo 2018). Clearly, the EIF needs more testing in specific Non-PCE settings, but we hope the proposed modifications presented here will strengthen the applicability of the model to a wider range of contexts.

(C) James D'Angelo and Saya Ike, 2020
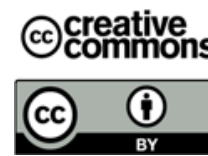

This work is licensed under a Creative Commons Attribution 4.0 International License https://creativecommons.org/licenses/by/4.0/

\section{REFERENCES}

Adachi, Masayuki. 2007. "International English" and English education in Japan. Obirin studies in English language and literature 47. 1-15.

Andonian, Andre, Tasuku Kuwabara, Naomi Yamakawa \& Ryo Ishida. 2016. The Future of Japan's Tourism: Path for Sustainable Growth Towards 2020. Retrieved from https://www.mckinsey.com/ /media/mckinsey/industries/travel\%20transport $\% 20$ and $\% 2$ 
0logistics/our\%20insights/can\%20inbound\%20tourism\%20fuel\%20japans\%20economic $\% 20$ growth $/$ the $\% 20$ future $\% 20$ of $\% 20$ japans $\% 20$ tourism $\% 20$ full $\% 20$ report.ashx (accessed: 10 June 2019).

Atkinson, Hoffman. 1879 [2007]. Exercises in the Yokohama Dialect: Revised and corrected at the special request of the author by the 'Bishop of Homoco'. In Kingsley Bolton \& Braj B. Kachru (eds.), Asian Englishes 5. 445-480. London: Routledge.

Backhaus, Peter. 2005. Signs of multilingualism in Tokyo - a diachronic look at the linguistic landscape. International Journal of the Sociology of Language 175/176. 103-121. DOI: 10.1515/ijs1.2005.2005.175-176.103.

Backhaus, Peter. 2006. Multilingualism in Tokyo: A look into the linguistic landscape. International Journal of Multilingualism 3 (1). 52-66. DOI: 10.1080/ 14790710608668385.

Backhaus, Peter. 2007. Linguistic Landscapes: A Comparative Study of Urban Multilingualism in Tokyo. Clevedon; Buffalo: Multilingual Matters.

Buschfeld, Sarah \& Alexander Kautzsch. 2017. Towards an integrated approach to postcolonial and non-postcolonial Englishes. World Englishes 36 (1). 104-126.

Buschfeld, Sarah, Alexander Kautzsch \& Edgar W. Schneider. 2018. From colonial dynamism to current transnationalism: a unified view on postcolonial and non-postcolonial Englishes. In Sandra C. Deshors (ed.), Modelling World Englishes in the 21st Century: Assessing the Interplay of Emancipation and Globalization of ESL varieties, 15-44. Amsterdam: John Benjamins.

Butler, Yuko G. 2007. Factors associated with the notion that native speakers are the ideal language teachers: An examination of elementary school teahcers in Japan. JALT Journal 29 (1). 7-40.

Carroll, Tessa. 2000. Language Planning and Language Change in Japan. Richmond: Curzon.

Chiba, Reiko, Hiroko Matsuura \& Asako Yamamoto. 1995. Japanese attitudes toward English accents. World Englishes 14 (1). 77-86. DOI: 10.1111/j.1467-971X.1995.tb00341.x.

D'Angelo, James. 2008. The Japan context and the Expanding Circle: A Kachruvian response to Debbie Ho. Asian Englishes 11 (2). 64-74.

D'Angelo, James. 2016. A Broader Concept of World Englishes for Educational Contexts: Applying the 'WE Enterprise' to Japanese Higher Education Curriculum. Vaal Triangle Campus Library, South Africa: North-West University (PhD thesis).

D’Angelo, James. 2018. Editorial. Asian Englishes 20 (3). 1.

Edwards, Alison. 2016. English in the Netherlands: Functions, Forms and Attitudes: John Benjamins.

Fujiwara, Yasuhiro. 2012. Identifying trends of English lexical borrowings from Japanese. Asian English Studies 14. 21-42.

Greisamer, Michael. 2006. Attitudes of Japanese university ESL learners: A contextual motivation survey. Kobe Shinwa Studies in English Linguistics and Literature 25. 94-112.

Hashimoto, Waka. 2006. 朝日新聞社説の外来語: 出自別推移を中心に. [Loanwords in Asahi Shimbun: Focus on changes in resource]. Doshisha Kokubungaku 64. 178-186.

Higuchi, Seiichi. 2007. The book market of Japan. Paper presented at the Breakfast Meeting, Frankfurt, Germany. http://www.jbpa.or.jp/en/pdf/bookmarket.pdf (accessed: 10 June 2019).

Hino, Nobuyuki. 2008. Kokusai-eigo [English as an International Language]. In Sue Kotera \& Hiro Yoshida (eds.), Supesharisuto ni yoru eigo-kyoiku no riron to oyo [Theories and Practice of English Language Teaching by Specialists], 15-32. Tokyo: Shohakusha. 
Hino, Nobuyuki. 2012. Endonormative models of EIL for the Expanding Circle. In Aya Matsuda (eds.), Principles and Practices of Teaching English as an International Language, 28-43. Bristol: Multilingual Matters.

Hino, Nobuyuki. 2018. English as an international language for Japan: Historical contexts and future prospects. Asian Englishes 20 (1). 27-40.

Honna, Nobuyuki. 1995. English in Japanese society: Language within language. Journal of Multilingual and Multicultural Development 16 (1-2). 45-62.

Honna, Nobuyuki. 2008. English as a Multicultural Language in Asian Contexts: Issues and Ideas. Tokyo: Kuroshio Publishers.

Honna, Nobuyuki \& Ulrike H. Meinhof. 1999. English in Japanese society: reactions and directions. In David Graddol \& Ulrike H. Meinhof (eds.), English in a changing worldL'anglais dans un monde changeant, 48-56. Oxford: AILA.

Honna, Nobuyuki \& Yuko Takeshita. 2000. English language teaching for international understanding in Japan. English Australia Journal 18 (1). 60-78.

Ike, Minoru. 1995. A historical review of English in Japan (1600-1880). World Englishes 14 (1), 3-11. DOI: 10.1111/j.1467-971X.1995.tb00335.x.

Ike, Saya. 2010. Backchannel: A feature of Japanese English. JALT 2009 Conference Proceedings, 205-215.

Ike, Saya. 2012. Japanese English as a variety: Features and intelligibility of an emerging variety of English. Melbourne: University of Melbourne (PhD).

Ike, Saya. 2014. Variety development in the Expanding Circle: Variety for EIL communication. In Ram Giri \& Roby Marlina (eds.), Enacting English across Borders: Critical Studies in the Asia Pacific, 104-122. Cambridge: Cambridge Scholars Publishing.

Ike, Saya. 2016. The interactional basis of backchannel behaviour in Japanese English. Journal of Sugiyama Jogakuen Universit: Humanities 47. 129-138.

Ike, Saya. 2017a. ELF in Linguistic Landscapes of Japan: Multilingual Services. Paper presented at the 10th Anniversary Conference of English as a Lingua Franca, ELF 10, Helsinki, Finland.

Ike, Saya. 2017b. Negotiating backchannel behaviour: Challenges in ELF communication. Journal of Sugiyama Jogakuen University: Humanities 48. 21-32.

Imura, Makoto. 2003. Nihon no Eigo kyouiku 200nen. Tokyo: Taisyukan.

Kachru, Braj B. 1985. Standards, codification and sociolinguistic realm: The English language in the Outer Circle. In Randolph Quirk \& H. G. Widdowson (eds.), English in the World, 11-30. Cambridge: Cambridge University Press.

Kim, Heejin. 2017. Language strategy and knowledge transfer. Organizational Science. 50 (4). 13-20. DOI: 10.11207/soshikikagaku.50.4_13.

Kodama, Koichi \& Satoko Kodama. 1979. Eigo/Kirisutokyo bungaku: Meiji no Yokohama. Tokyo: Sasama Shoin.

Kojima, Naoko. 2016. Eigo ni yoru gakushu (EMI) no genjo: EMI junbi ko-za no do-kizuke chosa kara [Current status of English Medium Instruction (EMI): Survey of motivation in EMI preparation courses]. Doshisha University Annual Report of Center for Learning Support and Faculty Development 7. 25-41. DOI: info:doi/10.14988/ pa.2017.0000014555.

Koscielecki, Marek. 2006. Japanized English, its context and socio-historical background. English Today 22 (4). 25-31.

Loveday, Leo J. 1996. Language Contact in Japan: A Socio-linguistic History. Oxford: Clarendon Press.

Makarova, Veronika \& Theodore Rodgers. 2004. English Language Teaching: The Case of Japan. Munich: LINCOM. 
McKenzie, Robert M. 2008a. The complex and rapidly changing sociolinguistic position of the English language in Japan: A summary of English language contact and use. Japan Forum 20 (2). 267-286.

McKenzie, Robert M. 2008b. The role of variety recognition in Japanese university students' attitudes towards English speech varieties. Journal of Multilingual and Multicultural Development 29 (2). 139-153.

Mesthrie, Rajend \& Rakesh M. Bhatt. 2008. World Englishes: The Study of New Linguistic Varieties. Cambridge, UK; New York: Cambridge University Press.

Mori, Arinori \& Toshiaki Ohkubo (eds.). 1972. Mori Arinori Zenshu. 3. Tokyo: Senbundo Shoten.

Murata, Kumiko, Mayu Konakahara, Masakazu Iino \& Noboru Toyoshima. 2018. An investigation into attitudes towards English as a Lingua Franca (ELF) in English-medium instruction (EMI) and business settings and its implications for English Language Pedagogy Institute for Advanced Studies in Education. Waseda Kyouiku Hyoron 32 (1). $55-75$.

Nakai, Motohiro. 2003. EFL students' perceptions of native and non-native speaking teachers. Gogakukyoiku kenkyuronsyu 20. 159-177.

Ohta, Yuzo. 1981. Eigo to Nihonjin. Tokyo: TBS Buritanika.

Saito, Yoshifumi. 2001. Eigo shurai to Nihonjin: Egeresugo kotohajime. Tokyo: Kodansha.

Saito, Yoshifumi. 2007. Nihonjin to Eigo: mouhitotsu no Eigo Hyakunen-shi. Tokyo: Kenkyusha.

Schneider, Edgar W. 2003. The dynamics of New Englishes: From identity construction to dialect birth. Language 79 (2). 233-281.

Schneider, Edgar W. 2007. Postcolonial English: Varieties around the world. Cambridge: Cambridge University Press.

Schneider, Edgar W. 2014. New reflections on the evolutionary dynamics of world Englishes. World Englishes 33 (1). 9-32.

Seargeant, Philip \& C. Tagg. 2011. English on the internet and a 'post-varieties' approach to language. World Englishes 30 (4). 496-514. DOI: 10.1111/j.1467-971X.2011.01730.x.

Seidlhofer, Barbara. 2001. Closing a conceptual gap: The case for a description of English as a Lingua Franca. International Journal of Applied Linguistics 11(2). 133-158.

Stanlaw, James. 2004. Japanese English: Language and Culture Contact. Hong Kong: Hong Kong University Press.

Takanashi, Kenkichi \& Kiyoshi Ohmura. 1975. Nihon no Eigo kyouikushi. Tokyo: Taisyukan.

Yamanaka, Nobuko. 2006. An evaluation of English textbooks in Japan from the viewpoint of nations in the Inner, Outer, and Expanding Circles. JALT Journal 28 (1). 57-76.

Yoshihara, Hideki, Yoko Okabe \& Seiko Sawaki. 2001. Eigo de keiei suru jidai [The Era Where we use English to Manage]. Tokyo: Yuhikaku.

Yoshikawa, Hiroshi. 2005. Recognition of world Englishes: Changes in Chukyo University students' attitudes. World Englishes 24 (3). 351-360.

\section{Internet Resources}

ETS. 2018a. 2017 TOEIC report on test takers worldwide. URL: https://www.ets.org/ s/toeic/pdf/2017-report-on-test-takers-worldwide.pdf (accessed: 10 June 2019).

ETS. 2018b. Test and Score Data Summary for TOEFL iBT ${ }^{\circledR}$ Tests: January 2017- December 2017 Test Data. URL: https://www.ets.org/s/toefl/pdf/94227_unlweb.pdf (accessed: 10 June 2019).

Japan National Tourism Organization. 2003. Japan Launches the Visit Japan Campaign. URL: https://us.jnto.go.jp/press/press_item.php?past=0\&prid=11 (accessed: 10 June 2019). 
Japan National Tourism Organization. 2018. Trends in Visitor Arrivals to Japan. URL: https://statistics.jnto.go.jp/en/graph/\#graph--inbound--travelers--transition (accessed: 10 June 2019).

MEXT. 2002. Developing a Strategic Plan to Cultivate "Japanese with English Abilities". URL: http://www.mext.go.jp/english/news/2002/07/020901.htm (accessed: 10 June 2019).

MEXT. 2003. Regarding the Establishment of an Action Plan to Cultivate "Japanese with English Abilities". URL: http://www.mext.go.jp/english/topics/03072801.htm (accessed: 10 June 2019).

MEXT. 2013. Global-ka ni taio shita Eigo kyouiku kaikaku jisshi keikaku [Action plans for English education improvement for Globalisation]. URL: http://www.mext.go.jp/a_menu/kokusai/gaikokugo/_icsFiles/afieldfile/2014/01/31/1343 704_01.pdf (accessed: 10 June 2019).

MEXT. 2014. Press Release Selection for the FY 2014 Top Global University Project'. URL: http://www.mext.go.jp/b_menu/houdou/26/09/_icsFiles/afieldfile/2014/ 10/07/1352218_02.pdf (accessed: 10 June 2019).

SDL. 2018. SDL Trados Studio. URL: https://www.sdltrados.com/ (accessed: 10 June 2019).

Statista. 2018. Number of social network users in Japan, 2015-2022. URL: https://www.statista.com/statistics/278994/number-of-social-network-users-in-japan/ (accessed: 10 June 2019).

\section{Article history:}

Received: 31 March 2020

Revised: 13 July 2020

Accepted: 15 July 2020

\section{История статьи:}

Дата поступления в редакцию: 31 марта 2020

Дата принятия к печати: 15 июля 2020

\section{Bionotes:}

James F. D'ANGELO, Ph.D. is Professor and Chair of the Global Liberal Studies Major at Chukyo University, Nagoya JAPAN. He is editor-in-chief of the Taylor \& Francis journal Asian Englishes, and serves on the Advisory Board of Routledge Advances in Teaching English as an International Language book series. He has authored various articles and book chapters, including 'The Status of ELF in Japan' in the Routledge Handbook of English as a Lingua Franca, and is co-editor of (Springer) Functional Variations in English published in Autumn 2020. Areas of research include world Englishes, EIL, English as a Lingua Franca, and EMI in Japanese higher education.

\section{Contact information:}

Chukyo University

Yagoto Honmachi 101-2, Showa-ku, Nagoya, Japan 466-8666

e-mail: dangelo@lets.chukyo-u.ac.jp

ORCID ID: 0000-0002-3030-2304

Saya IKE is Associate Professor, Meijo University, Nagoya, Japan. She serves as leadhandling-editor of Taylor \& Francis journal Asian Englishes. Her research interests include Pragmatics in interaction, Interaction Analysis, along with world Englishes and English as a Lingua Franca. Her most recent publication includes a co-authored chapter in Modelling 
World Englishes: A Joint Approach towards Postcolonial and Non-Postcolonial Englishes (Edinburgh University Press, 2020).

\section{Contact information:}

Faculty of Foreign Studies, Meijo University

4-102-9 Yadaminami, Higashi-ku, Nagoya 461-8534, Japan

e-mail: saya@meijo-u.ac.jp

ORCID ID: 0000-0002-4905-1357

\section{Сведения об авторах:}

Джеймс Ф. Д'АНДЖЕЛО, Ph.D., профессор, зав. кафедрой глобальных либеральных исследований в Университете Тюкё, Нагоя, Япония. Главный редактор журнала Asian Englishes (Taylor \& Francis). Состоит в редколлегии книжной серии "Routledge Advances in Teaching English as an International Language". Автор многочисленных статей и глав в книгах, в том числе в книге "Routledge Handbook of English as a Lingua Franca". Является соредактором книги "Functional Variations in English" (Springer, осень 2020). Научные интересы: варианты английского языка, английский как международный язык, английский как лингва франка, английский язык как средство обучения в высшем образовании Японии.

\section{Контактная информация:}

Chukyo University,

Yagoto Honmachi 101-2, Showa-ku, Nagoya, Japan 466-8666

e-mail: dangelo@lets.chukyo-u.ac.jp

ORCID ID: 0000-0002-3030-2304

Сая ИКЭ - доцент, Университет Мэйдзё, Нагоя, Япония. Возглавляет отдел передовых статей журнала “Asian Englishes” (Taylor \& Francis). Ее научные интересы включают прагматику взаимодействия, анализ взаимодействия, а также варинты английского языка и английский язык как лингва франка. Одна из недавних публикаций глава в соавторстве в книге "Modelling World Englishes: A Joint Approach towards Postcolonial and Non-Postcolonial Englishes" (Edinburgh University Press, 2020).

\section{Контактная информация:}

Faculty of Foreign Studies, Meijo University

4-102-9 Yadaminami, Higashi-ku, Nagoya 461-8534, Japan

e-mail: saya@meijo-u.ac.jp

ORCID ID: 0000-0002-4905-1357 